\title{
SOCIOLOGIE, NEBO ZDRAVÝ ROZUM? ${ }^{1}$
}

\author{
† MILOSLAV PETRUSEK
}

Otázka po vztahu sociologie a zdravého rozumu byla položena nesčíslněkrát a není nesnadné pochopit proč. Každý z nás je přece „sociolog-amatér“ nebo přesněji - laický sociolog alespoň v tom smyslu, že „nějak“ společnosti přece musíme rozumět, chceme-li a dokážeme-li v ní žít. Absolutní většina lidí pro „normální život“ ve společnosti nikdy žádnou sociologii nepotřebovala a - řečeno slovy amerického sociologa O’Neilla - lidé svůj život ve společnosti dnes a denně žijí a interpretují a nečekají na to, až přijde sociolog a poradí jim, jak se to dělá (O’Neill, 1972, s. 54; ale také O’Neill, 1975). Spíše než sociologa potřebují dobré rodiče, učitele, kolegy a nadřízené, slušné společenské klima, které člověka neznásilňuje, a trochu elementárních předpokladů k solidnímu lidskému živobytí. Mezi tyto předpoklady však sociologické vědění nepatří - rozhodně není „funkcionální nezbytností “ $\mathrm{k}$ přežití ve společnosti jiných lidí.

Velmi radikálně stanovisko umírněné distance $\mathrm{k}$ „pýše sociologie jako normální vědy (v kuhnovském smyslu)“ zformuloval Zygmunt Bauman takto: „Humanitní vědní obory, jež jsou nikdy nekončícím výkladem o lidském světě, jsou a pro všechny věky budou druhotnou hermeneutikou, ${ }^{2}$ interpretací toho, co existuje jen proto a jen díky tomu, že už interpretováno bylo; humanitní vědní obory jsou rafinovaným a vybraným, i když nenasytným př́živníkem na těle zdravého rozumu, přestože dělaly mnoho a nepochybně ještě udělají pro to, aby stopy svého původu zahladily“ (Bauman, 2006, s. 126).

K čemu je tedy sociologie dobrá, jestliže si téměř všichni lidé, téměř vždycky a téměř ve všech sociálních situacích vystačí se zdravým rozumem? Co se „sociologickou hermeneutikou“, jestliže si „lidská hermeneutika zdravého rozumu“ docela dobře vystačí? A proč sociologie „zametá stopy po svém původu“? Proč nepřizná, že „parazituje“, vždyt” i jmelí je parazit... Skeptických odpovědí tedy známe mnoho a další samozřejmě nabídneme k hlubšímu zamyšlení.

1 Poznámka editorů Jakuba Mlynáře a Miroslava Paulička: Rádi bychom zde především poděkovali Aleně Miltové, která nám tento nevydaný text z pozůstalosti profesora Petruska laskavě poskytla. Rukopis měl původně být kapitolou knihy s pracovním názvem Co je sociologie (Úvod do obecné sociologie), která měla též neoficiální titul Všechno, co vím o sociologii. Autor na knize pracoval od 90 . let, velká revize celkové koncepce a jednotlivých textů pak proběhla v roce 2004. V rukopise jsme provedli jen nejnutnější formální zásahy, které spočívaly zejména v úpravě citačního formátu a sestavení seznamu literatury. Na některých místech jsme Petruskovy odkazy upřesnili, vždy jsme tak ovšem učinili v poznámkách pod čarou uvedených jako „poznámky editorü“, nikoliv př́mo v textu samotném.

2 Hermeneutikou zde předběžně rozumíme v obecném smyslu ,výklad textưđ, v nejširším slova smyslu - „textem“ je vyprávění i kniha, autobiografie i ideologický systém. Všechna tato „verbální vyjádření světa“, každodenního i filozofy „,konstruovaného“, vyžadují, aby jim bylo rozuměno. Od dob Schleiermacherových se hermeneutikou zabývala řada významných myslitelů, $\mathrm{z}$ novověkých snad nejvlivněji Heidegger, Husserl a Gadamer. Bauman sám svou sociologickou metodu nazývá „sociologickou hermeneutikou". 
Nejprve si však vypomůžeme jednoduchou analogií. Dokud jsme zdraví a čilí, zdá se nám, že žádného speciálního biologického či medicínského vědění nejen nám, ale vlastně vůbec není třeba. Jste-li postmoderně vzdělaní intelektuálové, budete dokonce uvažovat o tom, že „vědecký rozum“ nemá žádnou prioritu nad jakoukoliv jinou formou poznání nad magií, alchymií, mýtem a samozřejmě už vưbec ne nad zdravým rozumem a obrátíte se nikoliv k „moderním šarlatánům“ descartovské vědy, ale k alternativní medicíně s jejími guru a samozřejmě - jak jinak - i drobnými podvodníčky. V klasické podobě tuto tezi (i tento způsob chování) formuloval nevýznamnější ze soudobých antiscientistů Paul K. Feyerabend (srv. Feyerabend, 2001). Kolem této myšlenky, jíž se říká „teze o deprivilegovanosti vědeckého rozumu“, se v sociologii rozvinula velká diskuse. Overington (1979) zdůrazňuje, že jde o důsledek vlivu koncepce T. S. Kuhna, podle níž věda není svou povahou kumulativní (tzn. neshromažduje soustavně a v dlouhodobé časové řadě poznatky spolu s paralelním vylučováním poznatků, jež se neosvědčily), ale že se vyvíjí v dramatických skocích proměn paradigmat (v tzv. paradigmatických revolucích). Zejména však zdůrazňuje závislost sociologického (a každého vědeckého) vědění na názoru vědecké komunity, tj. společenství profesionálních vědců, kteří s konečnou platností rozhodují o tom, co se dnes (hic et nunc) bude a co nebude pokládat za vědecké. Overington dodává: „Kuhnova koncepce předkládá historický, sociálně kontextový a komunitní charakter vědeckého vědění, který sám podkopává privilegovaný status tohoto věděni'“ (1979, s. 5). Vědění sice je prohlášeno za vědecké př́islušnou vědeckou komunitou (tedy například skupinou autoritativních, většinou dostatečně starých a laury ověnčených sociologů), „nic však v Kuhnově koncepci nepoukazuje na to, že by autorita sociologické komunity měla mít nějaká specifická privilegia: jsou to přece lidské skupiny, které Kuhnova koncepce zbavuje výsady býti speciálně obdařeny schopností věštit pravdu“ (Overington, 1979, s. 7).

Jde o naprosto principiální otázku, což svým vstupem do diskuse doložil i významný sociolingvista Dell H. Hymes (1979), který sociologům doporučuje, aby „byli tolerantní ke všem formám a varietám racionality“ a nespoléhali se na to, že se sociologům uvěří jen proto, že jsou „vědci“: proč by měl kdokoliv bezvýhradně akceptovat to, co sociolog říká? Rozumí sociolog společnosti opravdu lépe než obyčejný člověk? Hymes uvádí závažnou a mnohé osvětlující paralelu či analogii - zná lingvista jazyk lépe než jeho uživatel? Jak patrno, ani zde není odpověd' úplně jednoznačná. Rozhodně není na dlani.

To všechno - ve vztahu ke všem vědám, sociologii, lingvistice, fyzice či medicíně můžeme směle tvrdit a předpokládat, dokud jsme zdrávi a nic nás př́liš nebolí. Jakmile „Vznikne problém“, třebas v podobě malé černé tečky na plicích, o jejíž povaze a budoucnosti zatím nic netušíme, obvykle se mlčky skloníme před tradicemi a výsledky „descartovské vědy“, necháme se vyšetřit tomografem či alespoň rentgenem, podstoupíme desítku velice standardních testů, jež se opírají o velice standardní, protože určitým pravidlưm podléhající vědění, tedy o klasickou vědu či presněji o vědění, jež se tradičně a klasicky za „vědu“ označuje a pokládá.

Podobně je tomu se sociologií v moderní, komplexní společnosti, společnosti, jež je složitá provázaností a téměř totální vzájemnou závislostí prvků, z nichž je složena - ekonomiky na politice, náboženství na ekonomice, vzdělávacího systému na systému hodnotovém, politiky na postojové orientaci obyvatelstva a navíc závislostí toho všeho na technice, technologiích a informačních systémech. Zhroucení či alespoň oslabení nebo 
podstatná proměna kteréhokoliv z nich může vést $\mathrm{k}$ neočekávaným důsledkům - pozitivním, ale i kritickým, krizovým a sociálně destabilizujícím. V takových situacích, kdy vzniká sociální problém, sociálně problémová situace, si obvykle pouze se zdravým rozumem neporadíme. Politici, veřejné i ekonomické instituce, ale i osvícení mediální pracovníci se začnou pídit po sociologických expertizách a stanoviscích sociologů. Tím, že se sociologie vyjadřuje k sociálním problémům, se její poslání jako vědy ovšem zdaleka nevyčerpává. Ukazuje se tím jenom to, že v některých situacích prostě se zdravým rozumem nevystačíme (nebo si to aspoň někteří lidé, snad dokonce ti osvícenější, upřímně myslí).

\section{Scientismus a antiscientismus na přelomu tisíciletí: naivní scientismus}

Tím ale ani zdaleka netvrdíme, že nelze mít žádné výhrady proti tomu, co se souborně označuje jako „moderní věda“, ani že sdílíme představy obvykle označované jako naivní scientismus.

Naivní (někdy „vulgárni“) scientismus totiž předpokládá, že:

- věda je schopna sama vyřšit problémy, které vznikly jejími aplikacemi; například technický rozvoj jako ztělesnění moderní karteziánské vědy zpơsobuje ekologické problémy, které jsou podle scientistických předpokladů řešitelné zase jen vědeckými prostředky a nijak jinak ${ }^{3}$;

- „skutečná“ věda je exaktní, přesná a vlastně v jistém ohledu neomylná, v každém případě „skutečně pravdivého věděni“ o světě se dosahuje jen vědeckými prostředky, všechny ostatní formy vědění a způsoby poznávání světa (náboženství, umění, magie, mýtus, ale samozřejmě i „zdravý rozum“) jsou nutně z povahy věci méněcenné;

- věda je ve svém růstu neomezená, což se empiricky dokládá faktem exponenciálního přírůstku „vědeckého vědění. Dnes ostatně žije na světě 80 procent všech vědců, kteří kdy žili, a objem vědeckého poznání se každých pět let zdvojnásobuje: říká se tomu informační exploze, jež je podle scientistů samozřejmě řě̌itelná zase jen vědeckými prostředky, tedy především novými informačními technologiemi. Informační společnost, $\mathrm{k}$ níž samožrejmě směřujeme a jež proměňuje planetu v macluhanovskou "globální vísku“" (jež je propojena mediálními sítěmi, ale také vědomím možnosti atomové apokalypsy, ekologického zhroucení a apokalypsy ohrožení pandemie AIDS), v níž všichni lidé a všechna společenství budou propojena internetem či něčím samozřejmě ještě dokonalejším, vidí scientisté jako něco vysoce žádoucího, co nás dokonce přiblíží rousseauovské vizi přímé demokracie ${ }^{4}$;

3 Zygmunt Bauman uvádí jako exemplární případ masmediální adorace scientistického přístupu ke světu slavný film Den nezávislosti: planeta ohrožená nebezpečnou mimozemskou civilizací si v kritické situaci dokáže poradit prostě proto, že dovede „vyřešit problém“, protože „všechno je problém, který se dá s pomocí techniky a profesionálního vědění štastně vyřešit“: Konec světa? Tot přece jen další úloha pro počítač... (Petrusek \& Reifová, 1997, s. 208).

4 S touto ideou kriticky koketoval proslulý futurolog Alvin Toffler ve všech svých pracích $(1985,1991$, 1992, 1994). Jeho kategorická teze zní - „musíme redefinovat demokracii pro 21. století, nebo upadneme znovu do doby temna. Jedna z cest vede od státu k individuu" (Toffler, 1991, s. 364). Toffler apeluje na tvorbu shromáždění pro budoucnost společnosti, jež by se zabývala společenskou inventurou a definováním priorit $\mathrm{v}$ jednotlivých oblastech společenského života pro konec století (Toffler, 1992, s. 229). K tomu všemu dnes disponujeme technickými zařízeními, ale - realita Tofflerovy anticipační 
- věda je hodnotnější než „nevěda“, protože je nejvyšši kulturní hodnotou a je postačující podmínkou lidského štěstí. Tato scientistická teze, kterou ani zdaleka nesdílejí pouze vědci sami (podílníky na ní jsou nepřímo vlastně všichni ti, kteří jsou zaujati, nadšeni, fascinováni nebo zotročeni zejména moderními informačními technologiemi), má ovšem své počátky již v osvícenství konce 18. století a svých triumfů dosahovala ve století devatenáctém.

Dřive než se vrátíme na konec 18. století (a bez tohoto návratu ničemu neporozumíme), připomeňme pozoruhodnou poznámku Helmuta Schroecka, který nachází psychologické vysvětlení scientismu nikoliv v síle, ale slabosti lidského ducha - takto: „Scientismus nejen posiluje módy a koníčky soudobé sociologie (zde Schroeck zjevně naráží na slavnou Sorokinovu kritiku scientistní sociologie - pozn. MP), ${ }^{5}$ ale sám je symptomem světového názoru nejistoty, negativní sociální filozofie. Určité modely společnosti jsou atraktivní pro lidi, kteří se cítí nejistě, protože jim dávají naději na to, že lze svět stabilizovat, dokonce snad zmrazit“ (cit. podle Bauman, 1962, s. 10). Tato myšlenka se ve světle postmoderní diskuse o „fragmentarizaci“ světa jeví jako nikoliv zanedbatelná: soudobý scientismus lze stále znova interpretovat jako úsilí po rovnováze, negativně řečeno - jako neochotu žit v nestabilním, chaotickém světě. ${ }^{6}$

Mnozí postmoderní sociologové, ale i ti, kteří jsou k postmodernismu řazeni ne zcela právem (např. Zygmunt Bauman), nás ale důrazně upozorňují, že život ve „fragmentarizovaném světě“ je osudem člověka „pozdní modernity“, tedy naší doby. Bauman o našem světě mluví jako o tekuté modernitě, v níž pevnost a řád ztratily svůj původní význam a smysl, lidské aktivity i prožitky se staly „instantními“, na jedno použití atd. (srv. Bauman, 2002). Věda byla kdysi - a pro řadu lidí je dodnes - sférou jakési jistoty, protože se zvnějšku jako stabilní a pevná jeví. Uvidíme, že jako celá řada, ba většina jiných sociálních jevů (a věda je jev sociální), je i soudobá věda ve stádiu, které žádnou absolutní jistotu člověku v pozdně moderním světě nezajištuje. Vztah „věda - zdravý rozum“ se pouze proměnil v přímé závislosti na tom, jak se část lidstva stala vzdělanější (masarykovsky řečeno - „polovzdělanější “) na straně jedné a na tom, jak se věda stala nedostupnější (zejména ve svých poznávacích vrcholech) „prostému člověku“.

\section{Osvícenská představa o vztahu zdravého rozumu a vědy (filozofie)}

Kolem osvícenské představy o roli vědy a vědců se udržuje (zejména v postmodernistických koncepcích) jistý mýtus - jako by osvícenští myslitelé byli absolutně nekritickými stoupenci superiority vědy a inferiority zdravého rozumu.

či prognostické demokracie se nám jako horizont vzdaluje. Nezdá se, že by - zejména po pádu komunismu - byla sebemenší ochota vyměnit zaběhanou demokracii, v níž většina legitimuje volbami vládu politických elit, za jakousi „polobezprostřední internetovou experimentální demokracii.

5 Poznámka editorů: Zde se podle všeho jedná o Sorokinovu práci Fads and Foibles in Modern Sociology and Related Sciences (1956). Petrusek na tomto místě rukopisu ještě čtenáře odkazuje na „př́slušnou kapitolu této knihy“, čímž pravděpodobně má na mysli některou z dalších kapitol knihy o obecné sociologii (viz pozn. 1); tuto poznámku jsme ze závorky odstranili.

6 Podle některých autorů (srv. Gleick, 1996, s. 11) „chaos proráží hranice, které oddělovaly jednotlivé disciplíny... Teorie chaosu se zabývá problémy, které vzdorují tradičním pohledům vědy“. Dědictvím 20. století prý zůstane relativita, kvantová mechanika a teorie chaosu. 
Podstata osvícenského názoru je vyjádřena v hesle „Zdravý rozum“v proslulé Encyklopedii aneb Racionálním slovníku věd, umění a řemesel takto: „Kdyby prvotní pravdy nebyly rozšířeny v mysli všech lidí, bylo by nemožné, aby se lidé na čemkoliv shodli, protože by měli různé zásady, pokud by šlo o všechny druhy předmětů. I když je tedy správné říci, že pravda není pro davy, rozumíme tím jistý druh pravdy, který, aby byl chápán, předpokládá zvláštní pozornost, schopnost a zkušenost, což jsou výsady, které vůbec nejsou pro dav. Ale běží-li o prvotní pravdu, všichni jsou v tomto ohledu filosofy. Rozjímající filosof se všemi svými úvahami není o nic dokonaleji přesvědčen o tom, že existuje a myslí, než duch nejbezprostř̌ednější a nejprostší. V otázkách, při nichž je zapotřebí vědomostí získaných zvláštním usuzováním a uvažováním, což předpokládá určité zkušenosti, jež nejsou všichni schopni získat, můžeme filosofovi věřit více než jinému člověku... Jdu ještě dále: obyčejným lidem lze v některých věcech věřit více než mnohým filosofům, protože tito obyčejní lidé se vůbec nesnažili znásilnit nebo znetvořit city a úsudky, jež příroda vnuká všem lidem bez rozdílu“ (Soboul, 1954, s. 158).

Pozoruhodné na věci je to, že osvícenci, jak patrno z tohoto byt jen ilustrativního citátu, otevřeli některá velká témata, jež se stala předmětem systematičtějšího sociologického zájmu mnohem později, zejména:

1. Osvícenští filozofové (encyklopedisté) rozvíjejí slavnou Descartovu myšlenku, že „zdravý rozum je věcí, která je na světě nejlépe rozdělena“, předpokládají tedy že „monopol na pravdu“ nemají jenom učenci, vědci, filozofové (téma vztahu zdravého rozumu a vědy).

2. Existují však oblasti, v nichž se zdravým rozumem nevystačíme, oblasti, v nichž se k poznání dospívá prostřednictvím náročných postupů, které vyžadují jistou profesionalitu, předchozí průpravu a především znalost speciální metody, jež není rozdělena (podobně jako zdravý rozum) mezi všechny: vědecké poznání je v tomto ohledu superiorní a nelze je substituovat, nahradit zdravým rozumem (téma metody jako definičního znaku exaktní vědy).

3. Společenský konsensus je možný právě proto, že lidé sdílejí základní „prvotní pravdy“, jako např́ílad: „Na světě existují i jiné bytosti, než jsem já“, „Existuje něco, co se nazývá pravda, moudrost a obezřetnost, a toto něco není libovolné“ apod. Tyto prvotní pravdy později fenomenologie položí do základů tzv. přirozeného postoje člověka ke světu, protože člověk tyto pravdy bere jako dané (taken for granted) a nezměnitelné (téma přirozeného postoje, tzv. Lebenswelt a tzv. etnometod).

4. V osvícenské koncepci je rozlišen „filozof“ (rozuměj vědec) a „dav“, kteří nejsou na stejné úrovni, pokud jde o prrístup ke speciálnímu vědění: $v$ tom má vědec prioritu (téma společenských elit a téma superiority „vědeckého rozumu“).

5. Filozof (vědec) však snáze podléhá deformacím pohledu na svět, jimž se zdravý rozum dokáže snáze ubránit (téma ideologie jako deformace vidění sociální skutečnosti sociálními podmínkami a historickým a situačním kontextem).

Osvícenství tedy nejen jaksi mechanicky otevírá cestu ke scientismu, protože současně poukazuje na řadu problémů, jimž by se radikální scientisté nejraději vyhnuli. Radikální scientisté by totiž problémy poznání, zejména pak „poznání pravdy“ a kritéria pravdivosti našeho vědění nejraději položili výhradně do oblasti čisté gnoseologie (teorie poznání) a pominuli právě ony sociální souvislosti, jichž si byli již osvícenci poměrně dobře vědomi. Do centra pozornosti je proto položí programově nescientistický a antiscientistický 
postoj ve vědě a sociologii: všechno či téměř všechno vědění se začne jevit jako historicky, sociálně, jazykově, situačně, kontextově atd. podmíněné a tedy navýsost relativní, nezřídka nejednoznačné a z hlediska (absolutní) pravdivosti nerozhodnutelné.

Pro sociální vědy (a tedy i sociologii) má důsledná aplikace souhrnu radikálních scientistických předpokladů jediný myslitelný důsledek: aby sociologie byla vědou, musí být budována podle modelu přírodních (exaktních) věd, more geometrico, protože ty - zejména svými praktickým aplikacemi - prokázaly nejen svou sociální opodstatněnost, ale především svou „pravdivost“, svou způsobilost dosahovat „prověřeného“ a použitelného poznání. ${ }^{7}$

\section{Sociologie po způsobu geometrickém (more geometrico)}

Toto označení - more geometrico - se ujalo pod vlivem pokusu, který učinil holandský filozof 17. století Baruch Spinoza, když se pokusil vyložit etiku podobně, jako kdysi vykládal geometrii Eukleides, tedy tak, že z nedokazovaných axiómů deduktivně odvozoval další tvrzení (Spinoza pracuje s definicemi, axiómy, tvrzeními, důsledky, důkazy a poznámkami). Pravdivost všech jeho úvah o bohu, přirozenosti a pưvodu myšlení, o původu a přirozenosti afektů (ostatně sociologicky nejcennější partie celé Spinozovy Etiky), o moci rozumu a lidské svobodě (pasus milovaný klasickými marxisty, zejména Plechanovem, pro zde vyjádřený radikální determinismus) měla být zaručována evidencí výchozích postulátů (srv. Spinoza, 1986). Samozřejmě, že šlo více než o vážně myšlenou hru, ale rozhodně méně než o etickou geometrii či geometrickou etiku. Budovat sociologii podle modelu př́rodních věd už dávno neznamená budovat ji po vzoru geometrie, ale sám obrat „more geometrico“ se jako metafora ujal. K tématu se samozřejmě ještě několikrát volens nolens vrátíme - je to totiž osové obecně metodologické téma naší vědy.

Módy - podle vzoru které konkrétní vědy budovat sociologii - se měnily v závislosti na tom, která přírodní věda se zdála v daný moment „nejexaktnější. Český sociolog Otakar Machotka poznamenává velice přesně (žel tato úvaha byla pominuta, ač publikována v prestižním americkém časopise), že od jisté doby se „zamlčuje, že přírodní vědou se myslí obvykle fyzika, ačkoliv existují jiné přírodní vědy, jež mají objekt stejně komplexní a stejně rezistentní $\mathrm{k}$ měření a přesnosti jako jej mají sociální vědy - např́íklad geologie, geografie nebo meteorologie“ (Machotka, 1949, s. 15). Sociologie podle Machotky může pracovat oběma metodami či generálními postupy - „přirozeně“ i „laboratorně“, protože to jsou ostatně typy postupů, jež jsou univerzálně ve vědě přítomny. Lze lišit „laboratorní vědy“ (fyzika, chemie), které umožňují přesné, ale úzké pozorování, a „přirozené

7 Zajímavě je vzájemná závislost vědy a techniky vyjádřena v této Engelsově zajisté dobové úvaze: „Jestliže technika je většinou závislá na stavu vědy, je věda ještě daleko více závislá na stavu a potřebách techniky. Má-li společnost nějaký technický požadavek, pomáhá to vědě kupředu více než deset univerzit“ (Engels, 1978, s. 592). Marx i Engels byli přirozenými pokračovateli osvícenského přesvědčení o „všemocnosti vědy“, byli tedy klasickými scientisty a jejich pokus o konstrukci nové společnosti měl být nejen vědecky zdůvodněn, ale společnost sama měla být „vědecky rrízena“. Na rozdíl od Augusta Comta či Saint-Simona k tomu nepovolali ani filozofy či technokraty („kapitány průmyslu“), ale blíže nespecifikovaný proletariát, který se $\mathrm{v}$ toku dějin proměnil nejprve ve střední tř́du nepoužitelnou k revoluční akci a potom v masu byrokratických bossů, jež Milovan Djilas v 50. letech 20. století nazve „novou tř́́dou“ s osobitými ekonomickými a politickými privilegii. Engelsova vize o proletariátu jako přímém nositeli nejcennějších tradic „německé klasické filozofie“ se opravdu ani zdaleka nenaplnila. 
vědy“, jež se zabývají objekty v jejích přirozeném prostředí, tak, jak „jsou nám přirozeně dány“ (geologie, geografie). I v sociologii lze odlišit problémy laboratorního typu od problémů typu prirozeného. K prvnímu patří studium dětství, konfliktu, institucí, vlivu hustoty populace na běh jevů, ekologická studia aglomerací, kompetice atd., k druhému typu pak studium urbanizace, vývoje sociálních hnutí, studie jednotlivých vrstev a skupin (hobo, gangsteři, obchodníci), sociologické analýzy uměleckých děl a tvorby, náboženských hnutí atd. Ač uváděné př́iklady nejsou zcela přesvědčivé (pravděpodobným kriteriem rozlišení byla Machotkovi možnost intervence do probíhajícího procesu, př́padně míra sociologovy možné zúčastněnosti), Machotkovo shrnutí akceptovat asi lze: „Možnosti sociologie nejsou principiálně odlišné od přírodních věd. Závisí spíše na sociolozích než na předmětu jejich studií, jak dobré a jak vědecké budou jejich výsledky“ (Machotka, 1949, s. 17).

\section{Antiscientismus umírněný a radikální}

Oba popsané metodologické předpoklady - předpoklad naivního scientismu i předpoklad, že sociální vědy je nutné budovat more geometrico, jsou předpoklady př́liš silné a tedy v této (nekritické a jednoduché) variantě nepoužitelné: ačkoliv se v dějinách sociologie objevovaly, nikdy se neprosadily (většinou pro průzračnou naivitu svých postupů a jednoduchost až sterilitu věcných závěrů). Stejně nepřijatelný je však také současný velice módní antiscientismus, jakkoliv jeho jednotlivé teze přímo nabádají k tomu, abychom se přiklonili spíše k této optice, protože je - do značné míry však zdánlivě - ve větším souladu právě se zdravým rozumem.

Umírněný antiscientismus totiž tvrdí, že:

- věda má omezené možnosti, zejména v řešení specificky lidských problémů: ty jsou „vědeckými prostředky “ řešitelné málokdy a obvykle jen dočasně, náprava společenských poměrů prostředky vědy je neefektivní, ba dokonce nebezpečná (proto je poněkud paradoxně antiscientistou i reprezentant nejexaktnější sociální vědy, ekonom Friedrich von Hayek - ovšem tou částí svého díla, $\mathrm{v}$ níž vystupuje $\mathrm{z}$ rámce čistě ekonomického uvažování a vstupuje na půdu sociologicko-filozofickou a stává se tedy „intelektuálem“8);

- věda je k člověku lhostejná, je anonymní, depersonalizovaná a řeší nezřídka „problémy“, jež se lidských osudů vůbec netýkají, je někdy dokonce nadbytečná svým zájmem o věci, jež z hlediska každodenního života nemají žádný smysl;

- věda nedokáže ř rěit problémy, které sama vyvolala, a může přivést lidstvo ke katastrofě, což se dokládá atomovým útokem na Hirošimu, ohrožením lidstva genetickými experimenty, nezpůsobilostí řešit důsledky využití jaderné energie k energetickým účelům atd.;

8 Problém postavení intelektuálů ve společnosti je téma otevřené poprvé v souvislosti s Dreyfusovou aférou na přelomu století, kdy skupina vzdělanců využila své společenské autority k aktivnímu odporu vůči antisemitsky motivovanému soudnímu procesu. Julien Benda zpopularizoval téma intelektuálů slavnou brožurou Zrada vzdělanců (1929), na niž u nás reagoval zejména Šalda. Dnes se téma diskutuje znovu v souvislosti právě s tématem „deprivilegovanosti vědeckého rozumu“, někteří autoři pak akcentují rozpor mezi osobní morálkou intelektuálů a jejich veřejným politickým, tedy mimovědeckým engagement (Johnson, 1996). S mimořádnou pronikavostí téma uchopil Bauman v knize Legislators and Interpreters (1987) a u nás Bělohradský (1997). 
- věda je nekontrolovatelná, protože roste její neprůhlednost: věda 20. století je jiná než věda nedávné minulosti, protože je mj. ve svých teoreticky nejdůležitějších nebo nejzajímavějších partiích (napřv v teoretické fyzice nebo topologii) naprosto „nenázorná“;

- věda intervenuje, aniž si to většinou uvědomujeme, do naši každodennosti: prostřednictvím svých technických aplikací manipuluje naším volným časem, ovlivňuje povahu pracovního procesu, restrukturuje náš čas, „učí “ nás jiným zábavám, proměňuje náš životní styl; pouze díky vědě vznikla informační a technologická společnost, která vytváří základ životních stylů spjatých s moderními informačními technologiemi, stylů, jejichž důsledky zdaleka nedovedeme posoudit a dohlédnout;

- prostřednictvím expertů - specializovaných odborníků (nezapomínejme, že soudobá společnost se někdy označuje také jako „společnost věděni“ - rozuměj specializovaného) může věda legitimizovat jakoukoliv politickou moc - nebo naopak: politikové se mohou dovolávat vědy, aby legitimizovali svá rozhodnutí, a protože moderní věda je „neprůhledná“ a je možné v ni pouze „věřit“, lze legitimizovat i rozhodnutí velice nesprávná a nebezpečná;

- rozvoj technovědy či vědotechniky ${ }^{9}$ je možný jen v podmínkách relativně tuhé centralizace, takže ve svých důsledcích technověda ohrožuje demokracii.

Mezi sociology najdeme stejně tak optimistické scientisty a technologické optimisty (třebas Bell, Toffler, Fourastié) jako radikální antiscientisty (třebas Arendtová, Commoner). Problém vztahu sociologie a zdravého rozumu však není řešen zaujetím scientistického či antiscientistického stanoviska, protože ani radikální scientismus není totálním odmítnutím zdravého rozumu (protože by to bylo v rozporu nejen se zdravým rozumem, ale i s elementárními zjištěními např́iklad moderní psychologie) a ani jádrem radikálního antiscientismu není slepá adorace, zbožnění „zdravého rozumu“ jako spíše kritická distance od jednostrannosti exaktního vědění a skepse k možnostem vědy jako jediného, absolutně privilegovaného zpơsobu poznávání světa.

$\mathrm{V}$ tomto kontextu, který je posilován postmoderní kritikou vědy (o tom podrobněji dále) a modernistickou kritikou postmodernistického myšlení se strany „tradičních vědcư“, jakož i průnikem postmoderního myšlení do sociologie samotné, se odehrává spor o „vědu či zdravý rozum“, spor o „zdravý rozum či sociologické věděni“. Ač spor mnohokráte vedený, nikdy nedovedený do konce a stále znovu otevíraný.

\section{Poznatky zdravého rozumu a sociologické vědění}

Zdá se být samozřejmý tento předpoklad: má-li sociologie mít „status vědy“, má-li tedy být (podle standardních učebnicových definic vědy) systematickým užitím

- pozorovacích a experimentálních metod,

- teoretického myšlení,

- logického zdůvodnění vlastních argumentů k vytvoření

- určitého objemu reprodukovatelného a použitelného vědění,

9 Termín vědotechnika je termín Jana Patočky, který jím charakterizuje epochu průmyslové či technické civilizace, která „smetla - jak se zdá definitivně - jiné, starší pokusy lidstva utvářet, ba produkovat svůj život bez pomoci vědy a techniky, techniky založené na vědě, splývající v jistém smyslu s vědou“ (Patočka, 1990, s. 105). Patočka klade otázku, zda je technická civilizace úpadková a proč. 
nemůže přece být jenom opakováním „toho, co každý ví“ (Homans), nemůže být prostou, byt sofistikovanou, jen verbálně jinak vyjádřenou sumou „vědění zdravého rozumu“. Ale přece jen - nezřídka se zdá, že sociologie ničím víc není a ani ničím víc být nemůže, přijmeme-li totiž onu již uvedenou výchozí premisu, že každý je sponte sua, živelně, nechtěně laickým sociologem. Co jiného sociologii zbývá, než zjistit, čím se „průměrný“, „,obyčejný “ člověk řídí, v co věří, jak rozumí světu, jak v něm jedná, a právě toto v nějaké „systematizované“ podobě předložit jako „balík sociologického věděni““ (variace na termín Alfreda Schütze)?

A přece - tzv. samozřejmost sociologického vědění není ani zdaleka tak samozřejmá, jak se jeví na první pohled. Především uvedeme námitku naprosto zásadní - většina sociologického vědění se jako samozřejmá jeví, jakmile je vyslovena, tedy zformulována do podoby nějaké soustavy tvrzení, nějaké teorie či koncepce nebo zprávy o výsledku empirického výzkumu. Ve skutečnosti však až do doby prvního zveřejnění sociologického sdělení o „stavu světa“ (jeho fragmentu, segmentu, části) velmi často nikoho většinou ani nenapadlo, že by tomu mohlo být právě takto, že by sociální svět (jeho část, segment) mohl vypadat právě takto a mohl být právě takto vysvětlován. Jakmile je ale informace (vysvětlení, zpráva) sdělena, zdá se, že „není nic přirozenějšího“ a nic „samozřejmějšího“ než právě to, co sdělují sociologové. Uvedeme čtyři př́íklady:

1. Jedna vlivná sociologická teorie (tzv. teorie racionální volby ve variantě G. C. Homanse a B. Skinnera) vysvětluje celé sociální chování individuí jako směnu odměn a trestů a jako výsledek průniku dvou řad činitelů: zděděných dispozic intelektových a fyzických (genetická předurčenost a limitovanost) a sociálního učení. Člověk se sociálně učí tím, že společensky přijatelné jednání je odměňováno a nepřijatelné trestáno: v tzv. socializačním procesu se dítě právě takto sociálně učí tomu, co je užitečné, potřebné a nutné a co je naopak nepřijatelné, nepř́ípustné a zbytné. Sociální styk (interakce) mezi lidmi pak probíhá jako „směna odměn a trestů“: vzájemně se odměňujeme a trestáme za dobré či špatné chování. Ačkoliv lze mít tisícero námitek proti tomu, že například láska se „neredukuje“ na směnu odměn a trestů a že celé sociální jednání se nedá vysvětlit tezemi tak jednoduchými, jako jsou tvrzení elementární mikroekonomie a behaviorální psychologie, nelze popřít, že podstatná část sociálního chování jedinců na mikroúrovni (tedy na úrovni malých sociálních skupin a bezprostředního kontaktu) se právě takto vysvětlit dá. Jak to, že tato triviální myšlenka nenapadla nikoho do té doby, než Pavlov začal experimentovat se svými psy a Skinner se svými holuby a dokud Homans odvážně nevstoupil do „Skinnerova krysího labyrintu“, aby v něm hledal vysvětlení některých podstatných aspektů lidského chování?

2. Až do poloviny 20. století se mělo za to, že vztah mezi individuem a sociální skupinou může být bud’ vztahem členství (členská skupina, in group), nebo vztahem indiference či nepřátelství (cizí skupina, out group). Teprve ve 30. a 40. letech našeho století se objevila idea (nejprve u Hymana, poté u Mertona), že tento vztah může být daleko složitější - že individuum může být členem určité skupiny a současně touží být členem skupiny jiné (referenční skupina). Tento stav má řadu pozoruhodných sociálních důsledků, jež se nám dnes jeví jako zcela samozřejmé a pochopitelné. Ale jak to, že až do 40. let je nikdo neuměl řádně (nikoliv nutně teoreticky) vysvětlit, ačkoliv se o nich ze zkušenosti a z krásné literatury dávno vědělo? Jak to, že v předsociologickém uvažování na toto téma se nikomu nepodařilo zobecnění, které navrhl Merton, že totiž řada zdánlivě nepodobných a nesouvisejících jevů je vysvětlitelná tímtéž principem? 
3. Donedávna se o příčinách tzv. deviantního chování (například alkoholismu) uvažovalo většinou jen v rovině „etiologické“, tzn. že se hledaly př́mé kauzální souvislosti mezi nějakým sociálním činitelem a vznikem a udržováním alkoholové či drogové závislosti (např́klad rodinná situace, výchova, zděděná dispozice, vliv vrstevnické party či jiné sociální skupiny atd.). Teprve tzv. teorie etiketizace však přišla na to, že např́klad vyléčený alkoholik, který je i po vyléčení „stigmatizován“ jako alkoholik, který je jako alkoholik natrvalo označen (ř́káme, že je „etiketizován“) a od něhož se v jeho bezprostředním sociálním okolí očekává, že se jako alkoholik bude chovat, velice často začne pod vlivem této etikety také jednat: „At’ dělám, co dělám, stejně si o mně tak jako tak každý myslí, že chlastám, třebas tajně, takže jaký smysl má moje náprava či proměna? A hlavně - pro koho má smysl, není-li společensky ani vzata na vědomí?" Tomuto jevu ř́káme sekundární deviace a lze jím vysvětlit chování recidivistů stejně jako návrat polepšených dam k nejstaršímu řemeslu. Ale - jak to, že jsme tuto „naprostou samozřejmost“ objevili teprve před několika desetiletími? A jak to, že dodnes žijeme většinou v klamném předsudku, že alkoholik je nepolepšitelný, když jeho „polepšeni““ je v podstatné míre závislé na jeho sociálním okolí?

4. Až do Marxovy doby se o společenské struktuře neuvažovalo v kategoriích společenských tříd, pojem sám byl prakticky neznámý (ač objeven Guizotem a Thierrym) a jeho užívání se omezovalo na intelektuální kruhy historiků a později filozofů. Dokonce ani myslitelé francouzského osvícenství neměli společenské třídy v pojmoslovném repertoáru (mluvilo se přece o vzpouře „čtvrtého stavu“). Od Marxovy doby se o moderní společnosti bez pojmu třídy prakticky nedá uvažovat.

Martin Joseph ve své Sociologii pro každého (1986) přesvědčivě ukázal, kolik předsudků (a o ty jde hlavně) se nakupilo kolem pojmu třídy a kolem problému sociální struktury (včetně rasových a etnických vztahů, vztahů ke starým lidem atd.). Několik příkladů:

A1: (teze zdravého rozumu či - podle Josepha - obecně sdílený předpoklad): Třídy jsou dnes méně důležité než před 50 nebo 100 lety.

A2: (pravděpodobná skutečnost, tedy pravděpodobné sociologické vysvětlení): Třídy jsou stále významné. Př́́kladem je úmrtnost: je pravda, že naděje na dožití všeobecně vzrostla, míra úmrtnosti na základní „velká“ onemocnění je ale u nižších tříd (dělnictva) podstatně vyšší než u středních tříd.

B1: Můžeme se stát členy vyšších tříd, jestliže budeme pilně pracovat, snažit se a usilovat o to.

B2: Ve skutečnosti je společnost méně otevřená, než si myslíme. Vzestupná mobilita (sociální vzestup na hierarchickém žebřičku) je početně omezená a je obtížné se stát součástí společenské elity nebo vstoupit do elitních profesí.

C1: Někteří sociologové jsou posedlí třídami, ${ }^{10}$ ale většina obyčejných lidí se pokládá za svobodná individua, jež se mohou svobodně rozhodovat, pokud jde o volbu povolání, místo bydliště nebo trávení dovolené či volbu životního stylu.

10 To platí pro určitou, snad podstatnou část západní sociologie, nikoliv však sociologii naši. Po letech ideologické kastrace teorie tříd komunistickou ideologií se termín „třída“ stal téměř nežádoucí, protože jej sociologové nedovedou oprostit od ideologických konotací (zejména s tř́ídním konfliktem a bojem) a politikové třídním konfliktem straší v duchu logiky - vyženeme pojem, zaženeme realitu. Věcný spor o to, zda v naší společnosti existují „velké společenské tř́ídy“ a v jakém jsou vzájemném vztahu, se nevede. Jistou výjimkou jsou práce Pavla Machonina. 
C2: Sociologové pouze popisují, co se ve společnosti děje. Individua se cítí být svobodná, ve svých volbách jsou však podstatně ovlivněna zvyky, obyčeji, postoji a předsudky skupiny, k níž patří. V moderních společnostech takovou podstatnou skupinou je třída. Lze doložit, jak jsme závislí ve volbě povolání na rodinném původu, jak i péče o děti je tř́ídně diferencovaná (odlišná v různých sociálních vrstvách) atd.

Lze vést spor s Josephem i jinými (zejména neomarxisty) o relevanci kategorie tř́idy, ale nelze popřít, že bez této kategorie bychom soudobému světu málo rozuměli. Nemluvě ovšem o tom, že kategorie společenské třídy vstoupila do běžného vědomí v komunistických režimech jako etiketa, jako pozitivní nebo negativní označení (třídní původ jako determinanta postavení ve společnosti - s opačným znamením než v kapitalistických demokraciích). Na pojmu tř́da lze demonstrovat, co se stane, je-li sociologický pojem použit v ideologickém boji a společensky zneužit. Této ideologizaci (tj. spojení se zájmy určité konkrétní vrstvy či skupiny) ovšem podléhají i jiné společenskovědní pojmy, samy o sobě nevinné a s velkou výpovědní silou a hodnotou (trh, občanská společnost, otevřená společnost, sociální stát atd., ale i komplex méněcennosti, xenofobie, Oidipův komplex, industriální společnost, postmoderna atd.). Ale nejde vždycky o ideologizaci, někdy jde o „prostý fakt“ (označený Anthony Giddensem termínem reflexivita sociologického vědění), že sociologické vědění většinou ve fragmentarizované, zkratkovité, zjednodušené podobě spolu s některými „atraktivními“ pojmy vstupuje do běžného vědomí, stává se jeho součástí: pak už není nic, co bychom mohli označit jako „čistý“ zdravý rozum. Ve světě medií, ve společnosti mediální a informatické (případně ve společnosti vědění) je nemožné se právě tomuto procesu vyhnout. O to více záleží na tom, jaké sociologické vědění a jak je veřejnosti prezentováno.

\section{„Vědění“ zdravého rozumu ve světle empirického výzkumu}

Ačkoliv podstatnou složkou, vlastním vyústěním a završením každé vědy (včetně sociologie), je její teorie, tedy vysvětlení (sociálních) procesů a jevů, základní argumentaci pro sociologii jako vědění „privilegovanějši“, než je zdravý rozum, obvykle vedeme na úrovni empirického výzkumu. Výsledky empirických výzkumů totiž nezřídka dokazují zcela jednoznačně, že představy o určitých sociálních fenoménech založené na pouhém zdravém rozumu jsou chybné (předsudečné nebo prostě jen mylné). Navíc - zdravý rozum dokáže najít přesvědčivé vysvětlení i pro naprosto rozdílná tvrzení, tvrzení logicky kontradiktorní, jež tedy nemohou plynout ani z téhož empirického výzkumu ani je nemohou potvrdit dva nezávislé výzkumy, protože se prostě logicky vylučují. Robert Merton uvádí dvě takové explanace (vysvětlení, „miniteorie“), jež nabízí se samozřejmostí sobě vlastní zdravý rozum:

T1: Nezaměstnaní po dobu nezaměstnanosti čtou více než dřive. Vysvětlení: mají více času, nemají co dělat, nudí se, tedy čtou.

T2: Nezaměstnaní po dobu nezaměstnanosti čtou podstatně méně než dřive. Vysvětlení: stav nezaměstnanosti je stresující, zneklidňující, znemožňuje tedy soustředění na jakoukoliv náročnější intelektuální aktivitu, samozřejmě i na čtení.

Jak rozhodnout o tom, které z obou tvrzení je (statisticky významně) pravděpodobnější, jinak než prostřednictvím empirického výzkumu, jestliže zdravý rozum nabízí 
dvě rozporná, ale zdánlivě stejně přesvědčivá vysvětlení? Data empirických výzkumů ale ukazují řadu dalších pozoruhodností, jež mluví proti ustáleným a obecným představám zdravého rozumu a víceméně jednoznačně je vyvracejí. Pravděpodobně poprvé si s rozporem „sociologie versus zdravý rozum“ empiricky pohrál Samuel Stouffer se svými spolupracovníky ${ }^{11}$ při výzkumu chování amerických vojáků během druhé světové války v Tichomoří. ${ }^{12}$ Nabídl několik hypotéz (spolu s vysvětlením, proč jsou pravděpodobně „pravdivé“) a empiricky je prověřoval (testoval). Zde jsou některé z nich:

H1: Černošští vojáci si p̌rejí, aby mohli sloužit pod di̊stojníky a poddůstojníky černošského pưvodu (vysvětlení: Vzhledem k existující rasové nesnášenlivosti a často vzájemně agresivnímu chování je přirozené, že vojákovi se lépe slouží pod velitelem stejné barvy pleti, protože u něho nemůže předpokládat rasový motiv k nepřiměřenému zacházení).

H2: Vojáci z amerického Jihu lépe snášejí př́rodní (fyzikální) podmínky boje v Tichomoři (vysvětlení: Podobnost přírodních podmínek, vysoká teplota a vlhkost vzduchu činí vojáky z Jihu adaptabilnějšími na podobné tichomořské podnebí).

H3: Vojáci z měst jsou podstatně neklidnější než vojáci z venkova, jejich reakce na bojové podmínky jsou neurotičtější a obecně výskyt neurotických potiží je u nich vyšší (vysvětlení: Lidé $\mathrm{z}$ měst jsou obecně neurotičtější než lidé $\mathrm{z}$ venkova a válečná situace tuto dispozici jen posiluje).

„Vtip“ Stoufferova sdělení pak spočívá v tom, že přesvědčivost uvedených hypotéz je pouze zdánlivá: všechny byly empiricky vyvráceny, ukázalo se dokonce, že platí (statisticky významně) jejich přesně opačné formulace. Zdravý rozum ve zkoušce empirického testování tentokráte neobstál.

Podobně se zdá být samozřejmé, že platí předpoklad, že $v$ zemích s převažujícím katolickým obyvatelstvem (rozumí se: s výraznou většinou praktikujících katolíků) je ménè nemanželských dětí než v zemích ostatních. Prostá statistická čísla ale sdělují, že ve vysoce katolických zemích je tomu takto: ve Venezuele je $57 \%$, v Guatemale 70 \% a v Panamě $70 \%$ nemanželských dětí, zatímco v nekatolických Spojených státech pouze $2 \%$.

Př́klady lze dále rozmnožovat, třebas otázkou - v jakém typu společnosti je člověk pod větší sociální kontrolou: v preliterární společnosti původní tahitské komunity, nebo v industriálním velkoměstském společenství? Ačkoliv zdravý rozum se jistě přiklání k variantě první, ve skutečnosti prokazatelně platí, že sociální kontrola ve velkoměstském prostředí je podstatně silnější než v malých komunitách obecně a preliterárních zvláště. Nebo jiný př́iklad, který spadá do oblasti analýzy nepř́jemného předsudečného stereotypizovaného hodnocení odlišných ras. Bělošský rasismus se někdy projevuje ve známých vulgárních označeních Afroameričanů, Afričanů a Asiatů jako „černých“ či „žlutých“ „opic“. Použijeme-li však přesných antropologických měření, pak zjistíme tato fakta: Pokud jde o tvar nosu, mají k našim subhumánním předkům nejblíže černoši a nejdále běloši, pokud jde o tvar rtů, jsou nejblíže běloši a nejdále černoši, ve věci ochlupení jsou nejblíže opět bílí a nejdále žlutí, ve tvaru a barvě vlasů nejblíže žlutí a nejdále černoši, ve tvaru a barvě očí nejblíže žlutí a nejdále černí a konečně pokud jde o tvar čelisti, jsou

11 Poznámka editorů: Zde se patrně jedná o slavnou studii The American Soldier: Adjustment during Army Life (Stouffer et al., 1949).

12 U nás na tomto předpokladu, že totiž sociologie není sumou poznatků zdravého rozumu, postavili svou drobnou, ale kvalitní učebnici sociologických metod a technik J. Kapr a Z. Šafár (1969). 
nejblíže černí a nejdále bílí. Sečteno a podtrženo - jsme na tom zhruba stejně a rasistické označení „bílá opice“ by bylo antropologicky stejně „přesné“ jako vulgarismy obvyklejší. Zdravý rozum našich rasistů se svým „prostým pozorováním“ prostě neuspěl.

Velice známé jsou prŕíklady hypotéz, jež se týkají suicidálního chování, kdy empirická (statistická) data vyvracejí většinu hypotéz zdravého rozumu. Zkuste posoudit „jen“ pomocí zdravého rozumu, která z následujících tvrzení skutečně statisticky významně platí (a pokuste se je nejprve pomocí zdravého rozumu vysvětlit či zdůvodnit): Sebevraždy častěji páchají (1) ženy, (2) rozvedení, (3) lidé mladí, k sebevraždám dochází častěji v podmínkách (4) válečných, (5) ekonomické nouze, sebevraždy nepáchají (6) alkoholici a (7) děti, (8) nejčastější příčinou sebevražedného chování adolescentů jsou milostné a sexuální problémy.

Odpovědi na hádanku prostým rozumem jen tak neřešitelnou jsou pak tyto: (1) Ano, ale většinou jde o sebevraždy manifestační, tedy nedokonané (jedna dokonaná ženská sebevražda na tři mužské), (2) ano, rozvedení páchají sebevraždy častěji než jakkoliv (štastně či neštastně) ženatí či vdané, (3) u starších a starých lidí je sebevražednost vyšší než u mladých, (4) v podmínkách válečných sebevražednost klesá a (5) bída před sebevražedností „chrání, (6) alkoholici mají výrazně vyšší sklon k suicidálnímu chování alkohol ohrožuje, (7) sebevražednost u dětí dosahuje až $5 \%$, (8) láska a sexuální potíže tvoří cca $6 \%$ motivů k sebevražednému jednání (rodinný konflikt $40 \%$ ). ${ }^{13}$

Podobným zpo̊sobem sociologie vyvrací některé tradované mýty běžného vědomí, jako např́ílad představu, že romantická láska je přirozenou součástí lidské přirozenosti a že je proto základem všech společenství (ve skutečnosti je „sociální konstrukcí: zamilovanost není univerzální zkušenost lidstva, romantická láska vznikla až v pozdním středověku jako milostná hra aristokracie a teprve moderní společnost spojila emocionalitu, tedy lásku, se sexualitou a obojí s manželstvím a rodinou), že rodina $v$ minulosti byla stabilnější, než je dnes (proti tomu mluví údaj, že kolem roku 1800 bylo v Evropě podstatně více dětí, které žily pouze s jedním rodičem), že míra sebevražednosti je zhruba všude stejná, protože lidé jsou všude stejně neštastní (ve Velké Británii je sebevražednost čtyřikrát vyšší než ve Španělsku) nebo že v totalitních režimech je suicidální chování častější než v tradičních demokraciích (kolem roku 1975 byla ve Velké Británii sebevražednost třikrát vyšší než v Mad’arsku) atd.

13 Skutečně moderní sociologie podle některých autorů, např. Madge (1963), začíná slavnou prací Emila Durkheima Sebevražda z roku 1897. Je svým způsobem symbolické, že první českou sociologickou prací, byt psanou německy, je habilitační práce T. G. Masaryka Sebevražda jako hromadný jev moderní osvěty, která Durkheimovo dílo předešla o více než desetiletí. V této souvislosti si brněnský sociolog Střítecký položil pěknou provokativní otázku, zda se Masaryk mohl či nemohl stát „rakouským Durkheimem“, kdyby v roce 1882 neopustil Vídeň a nepřešel do Prahy. Stř́tecký odpovídá střízlivě (spíše záporně), navíc se dotýká našeho tématu. Masaryk shledával prvotní příčinu sebevražednosti v polovzdělanosti, v tom, že „věda se hromadně zmocnila myslí, které ještě včera nebyly s to přečíst jedinou řádku, což muselo oslabit přirozenou religiozitu a navíc vystupňovalo v masovém měřítku duchovní potřeby“ (dodejme v souladu s Durkheimem, že také materiální). Masaryk se tak jeví jako „konzervativní kritik demokratizace kultury a modernizace“, který vede trvalý svár mezi tímto v zásadě antiscientistním postojem a „staropozitivistickou, od Comta přejatou důvěrou v možnost lidsky důstojného překonání civilizační krize“ - věděním a vědou. Zde Stř́tecký odkazuje na Masarykův dopis Husserlovi, v němž mj. píše, že jen matematika se může stát klíčem $\mathrm{k}$ modernímu vědění... (srv. Stř́itecký, 1994, s. 24). Jak patrno, ani Masaryk to se svárem obou tendencí neměl lehké, navíc to byl jeho svár osobní, osobně prožívaný. 
Podobné i jiné př́klady uvádí ve své učebnici Anthony Giddens, který shrnuje: „Sociologická zjištění nejsou ovšem vždycky v rozporu se zdravým rozumem. Ideje zdravého rozumu často inspirují k hlubšímu vhledu do povahy sociálního chování. Musíme však zdůraznit, že sociolog musí být připraven klást si otázku nad našimi představami o nás samotných, at' už jsou jakkoliv hluboce zakořeněny - je tomu skutečně tak? ... Ostatně mnohé z toho, co pokládáme za vědění zdravého rozumu, za to, co přece každý ví, je založeno na práci sociologů a jiných sociálních vědcư“ (Giddens, 1989, s. 15).

Zdá se tedy, že empirický důkaz o tom, že pouze se zdravým rozumem nevystačíme, byl podán a že dalších komentářů netřeba. Uvidíme dále, že tak jednoduché to v našich vědách přece jenom není.

\section{Přednosti a omezení tzv. laické sociologie}

Tzv. laická sociologie, tedy naše běžné znalosti, „každodenní věděni““ o společnosti, je přirozeně založena nikoliv na studiu sociologických prríruček, ale vychází ze získané a naučené zkušenosti. Objem této zkušenosti je př́liš úctyhodný, než aby jej sociolog mohl úplně a nonšalantně ignorovat (ačkoliv, jak uvidíme, nemusí být vưči němu nekritický).

Je totiž nesporně pravda, že člověk, chce-li a má-li v dané konkrétní společnosti víceméně úspěšně žít, musí disponovat poměrně velkou zásobárnou vědění o společnosti. Zejména musí znát:

- jazyk daného společenství a pravidla komunikačního styku - to, co se označuje termínem symbolické univerzum (úhrn znaků a symbolů, jimž je nutné rozumět, aby se člověk ve společnosti orientoval, počínaje přirozeným jazykem a konče třebas piktogramy na záchodcích či v dopravních prostředcích), přričemž váha symbolického univerza roste přímo úměrně růstu role moderních informačních technologií a masových médií;

- základní sociální normy, tedy pravidla, jež v dané společnosti mají být dodržována a respektována (přičemž jde nejen o normy právní, náboženské či jiné, většinou písemně fixované, ale především o soubor nepsaných a nikde většinou explicite nevyslovených pravidel);

- systém sankcí, jimiž společnost dodržování pravidel odměňuje a jejichž porušování trestá;

- systémy očekávání, tj. jak jsou ve společnosti definovány sociální role, co se očekává od určitých sociálních pozic a v určitých sociálních situacích (včetně stereotypizovaného, vzorcovaného a ritualizovaného chování) ${ }^{14}$;

- způsoby interpretace sociálního světa, které jsou v daném společenství obvyklé.

To všechno se člověk sociálně učí jednak v procesu výchovy (v procesech socializace a enkulturace, tedy v procesech, jimiž se proměňuje z biologické bytosti v bytost sociální,

14 Jan Keller ve své knížce Dvanáct omyli̊ sociologie (1995) staví na kritice pojmu očekávání kritiku klasické i moderní sociologie a na kritice fenoménu očekávání kritiku pozdně moderní společnosti, která je generátorem umělých a nikdy úplně nenaplnitelných očekávání. Kellerova kritika je sice žánrově posazena do jiné než akademické polohy, věcně je v zásadě přijatelná snad s výhradou, že pojmy jsou nevinné: vyhnat „očekávání“ ze sociologie (třebas z definice role jako „očekávaného chování) je nejen zbytečné, ale výslovně kontraproduktivní. Na durkheimovské kritice lidské nenasytnosti (stimulované očekáváními produkovanými producenty) to přece nic nemění. 
která rozumí kultuře daného společenství tak, že může být její aktivní součástí), jednak v procesu aktivního sociálního života (sociální zkušenost). Kromě toho hraje významnou roli nápodoba, opakování určitých ustálených vzorců chování, v pozdně moderním světě se pak na vzniku nových vzorců každodenního jednání, mluvy a interakce, na jejich udržování a reprodukci způsobem zcela mimořádným podílejí hromadné sdělovací prostředky, masová média, která nabízejí skutečně nepřeberný repertoár vzorců chování (z nichž se jako ze skládaček puzzle tvoří partikulární životní styly) a způsobů interpretace událostí, jevů a procesů probíhajících v sociálním světě. Pro mediální prezentaci vzorců sociálního chování však začíná být stále více příznačné to, že předkládají sice velmi diferencovanou varietu životních vzorů, ale varietu neuspořádanou a bez návodu, který z nich si vybrat. Tím se liší postmoderní (mediální) svět od světa tradičně moderního, v němž dominoval řád, návod, tedy také instrukce, pravidla výběru a volby, jakož i sociální korekce přípustných jednání a dokonce sociálních očekávání. Přechod od společnosti represivní kontroly přes společnost „represivní tolerance“ (Marcuse) ${ }^{15}$ ke společnosti „permisivní, jež dovoluje téměř všechno, se odehrává před našima očima a proměňuje nejen společnost, ale i sociologii.

V moderních společnostech vstupuje do běžného vědomí také ekonomické, právní, filozofické, psychoanalytické i sociologické vědění - a nejen na úrovni, která byla dosažena formálním studiem a výukou ve školách různých stupňů. „Běžný člověk“, jak jsme se zmínili, dnes uvažuje v psychoanalytických kategoriích třebas oidipovského komplexu (dříve byl módní spíše adlerovský komplex méněcennosti), rozumí řadě ekonomických procesů a umí je alespoň pojmenovat, ne-li vysvětlit, běžně používá části sociologické terminologie (sociální nerovnost, elity, občanská společnost atd.), byt’ nikoliv vždycky přesně. Lze tedy souhlasit s názorem Paula K. Feyerabenda, že představa „prostého“ , „prüměrného“, „obyčejného“ člověka je představa mytologická, která je snad součástí tradičního sociologického folklóru, ale jíž v pozdně moderní společnosti vlastně nic neodpovídá: „Kdo to vlastně ten obyčejný člověk je? Vezmeme-li v úvahu, s jakým cílem se o něm mluví v různých diskursech, pak zjištujeme, že se předpokládá, že se nevyzná nejen ve vědě, ale ani v politice, náboženství a vưbec v čemkoliv. Znamená to, že v časech obecné komunikace a vzdělání si tento obyčejný člověk musí dávat převeliký pozor, aby nečetl některé části novin, aby jeho televizor nebyl prŕliš dlouho zapnutý a aby si nedopřával přiliš dlouhou konverzaci s přáteli nebo s dětmi. Jinými slovy - musí to být bud' bytost necivilizovaná nebo idiot" (Feyerabend, 1979, s. 146).

Všechno toto je asi pravda, takže se opravdu zdá, že není úplně bezdůvodné začít budovat sociologii na této tezi: Jestliže lidé dovedou přiměreně sociálně jednat, pak to znamená, že sociální situaci, $v$ níž žijí, také přiměreně rozumějí. Úkolem sociologie nemůže být nic více a nic méně než dosáhnout porozumění tomuto porozumění (tedy vysvětlit, jak lidé svou laickou sociologii budují a co je jejím obsahem).

A přece lze do tohoto typu uvažování vnést několik podstatných korekcí. Především běžné, každodenní vědomí (laická sociologie) samo sebe nereflektuje, tzn. neví nezřídka nic o svých „hlubinných strukturách a obsazích“. Platí zde analogie s jazykem: tzv. rodilý mluvčí, který si osvojil „mateřský jazyk“ v dětství, vůbec nemusí znát (a neumí samozřejmě vůbec rekonstruovat) gramatická pravidla, podle nichž mluví - a přece mluví

15 Poznámka editorů: Jde o odkaz na Marcuseho esej „Repressive Tolerance“ (1965). 
dobře a sociálně efektivně. Podobně ve sféře sociálního vědění lidé respektují obrovské množství norem, které neumějí vůbec vyjádřit, protože někdy ani přesně nevědí, kde ona norma leží, kde je situována. Lidé se např́íklad umějí „prostorově chovat“ (kupř́íkladu respektují určitou prostorovou vzdálenost při komunikaci s jinými lidmi), ale normy, jimiž se prostorové chování řídí, musela popsat až proxemika, věda o prostorovém chování, jež je svou podstatnou součástí sociologickou disciplínou (srv. zejména práce Hallovy). ${ }^{16}$ Lidé sice mají určitou představu o „normě manželské (či partnerské) věrnosti“, ale tato norma variuje podle věku, sociální příslušnosti, náboženského vyznání a přesvědčení atd., atd., a je úkolem sociologie právě tyto variace popsat a vysvětlit.

1. Lidé ve svém každodenním životě uvažují nutně $v$ omezeném prostoru a v omezeném čase, jejich sociální zkušenost je časoprostorově (a tedy i sociokulturně) omezená. Autoři slavné knihy Hranice růstu ${ }^{17}$ použili pro zobrazení této situace mřižky, která se stala do té míry proslulou, že nese jejich jméno (viz Schéma).

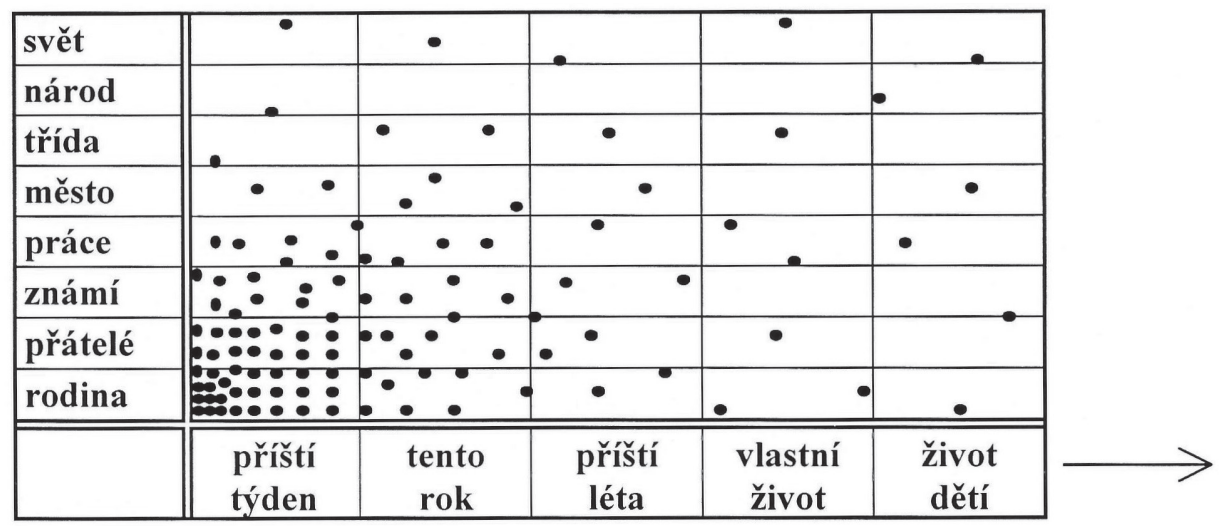

Schéma: Meadowsova mřížka

Je zřejmé, že většina našich zájmů je situována v levém dolním rohu schématu, což odpovídá postavení člověka ve společnosti, at je jakékoliv: hlavním předmětem našich činností, myšlenek, plánování i očekávání jsou skutečnosti spjaté s „obstaráváním“, s každodenním životem, s rutinou všedního dne. Ale právě tato skutečnost - velké téma „obstarávání“ a „každodennosti“ - musí být předmětem sociologického a filozofického zájmu. U nás toto téma otevřeli filozoficky Kosík v Dialektice konkrétního (1963) a Patočka v Kacírských esejích o filosofii dějin (1990), ve světové filozofii pak především Heidegger ve spise Bytí a čas, ve světové sociologii pak fenomenologická sociologie (Schütz a další) a etnometodologie.

2. Běžné vědění (laická sociologie) není strukturováno v žádný konzistentní logický celek, není souborem ověřitelných či falzifikovatelných (vyvratitelných) tvrzení a je dokonce ze značné části složeno z tvrzení, jejichž „pravdivost“ se nezkoumá a prověřová-

16 Poznámka editorů: Asi nejslavněǰ́í je Hallova práce The Hidden Dimension (1966).

17 Poznámka editorů: Jde o známou knihu manželů Meadowsových (1972), odkud je převzato i schéma. V knize má titulek „Human perspectives“. 
ní jejichž pravdivostní hodnoty se ani nepředpokládá. Proto je organickou součástí laické sociologie obrovské množství stereotypizovaných představ - až po předsudky nejrůznějšího druhu a podob. V běžném vědomí jsou zcela samozřejmé „sociologické výklady“ některých sociálních jevů pomocí „teorie spiknuti“, v níž se hledá obětní beránek (obvykle minoritní skupina etnická či sociální) atd.

3. Nelze pominout ani to, že existuje výrazný a prokazatelný rozpor mezi tím, co si lidé o věci myslí, a jak reálně sociálně jednají. Lidé se často pokládají za rasově snášenlivé („nejsem žádný rasista“), ale nezřídka jednají předsudečně, „rasisticky“ ve všech situacích, které to připouštějí. Ale i naopak - americké výzkumy ukázaly, že někteří „deklarovaní rasisté“ se v konkrétní sociální situaci chovají v rozporu se svým „přesvědčením“, tedy tolerantně a naprosto neagresivně. Prostý popis obsahu laické sociologie proto může podat jenom omezenou informaci o reálném sociálním chování - a o to jde v sociologii především!

4. A konečně - laická sociologie je vyjádřena v „běžném jazyce“. Přirozený, „nevědecký“ jazyk také nejlépe odpovídá potřebám každodenního života, nezbytnostem běžné komunikace. Avšak to, co je v přirozeném (běžném) jazyce předností, se ve „standardní vědě“ stává nevýhodou, někdy dokonce překážkou efektivní komunikace ve vědecké obci (a nejen v ní). Např́lklad mnohovýznamnost a metaforičnost přirozeného jazyka jsou výhodami v běžné komunikaci (a jsou jejím obohacením), ale výraznou nevýhodou při formulaci vědeckých hypotéz, tvrzení a teorií. Podle tradiční představy „standardní vědy má být každý vědecký pojem vymezen jednoznačně (což pro pojmy běžného jazyka zdaleka neplatí), a není-li to možné, je nutné zavést pojem nový a přiměřeně jej jednoznačně definovat. Tak vzniká vědecká terminologie, která se od výraziva běžného jazyka liší. Zatímco tato skutečnost neudivuje ve vědách exaktních, naráží na odpor vždycky, když si totéž právo (právo na vlastní terminologii) nárokuje sociolog. ${ }^{18}$

Předběžný závěr, který zdůvodněně plyne z předchozího rozvažování je tento: laická sociologie je organickou součástí každodenního života i sociologické vědy. Laickému vědění o společnosti nelze dostatečně porozumět bez sociologického vědění na straně jedné a sociologické vědění je neúplné, jestliže nerespektuje, že se zabývá světem, který je již interpretován, vyložen, pojmenován běžným vědomím, tedy laickou sociologií. Sociologie je - použijeme-li variace na schützovský motiv - „konstrukcí druhého stupně“. Konstrukcí prvního stupně je laická sociologie.

\section{Běžné vědění a zdravý rozum v sociologické reflexi}

\section{„Běžné vědomí" reálného socialismu a etnometodologie}

Dřive než se rozeběhneme proti toku času, učiňme tuto poznámku. V 70. a 80. letech se poměrně módním tématem „marxistické sociologie“v SSSR, Bulharsku, ale i u nás (v Polsku jinak a s jinými efekty) stalo téma „běžného vědomí. Oficiální sociologie té doby (ale

18 Se vstupem zejména postmoderního myšlení se situace změnila i v sociologii: použití metafory se z prohřešku proti pravidlům stalo považovanou ctností. Např́klad Baumanovy knihy o postmoderní situaci jsou někdy až do nesrozumitelna metaforické, ačkoliv si svůj sociologický ráz zachovávají. 
ani sociologie „šedé zóny“) se neodvažovala otevřeně poukázat na to, že jde vlastně o replikaci tématu, které otevřela v západní sociologii etnometodologie (Garfinkel aj.).

Etnometodologové totiž $v$ opozici proti tradičnímu pozitivistickému pojetí společnosti jako čehosi vioči člověku vnějšímu (společnost jako suma sociálních faktů, struktur a institucí) pochopili sociální svět jako cosi, co lidé neustále tvoří tím, že svému každodennímu životu dávají určitý smysl, smysl specifický a neustále se měnící, díky čemuž se však společnost pro ně stává srozumitelnou a předvídatelnou.

Jack Douglas přesvědčivě ukázal, že „absolutistický postoj“ tradiční sociologie (včetně jejích klasiků) vytlačuje do sociologického podvědomí skutečnost, že sociologie sama nemůže bez každodenního vědění, bez „porozumění každodennímu životu“ s jeho racionalizačními praktikami (etnometodami) prostě existovat. Ale co více - tradiční sociologie postuluje mimo jiné existenci „vyšší úrovně řádu společenských jevư“, které jsou jaksi mimo zdravý rozum, běžné vědomí a každodenní život. Je to předpoklad existence společnosti „mimo srdce a ducha jiných živoucích bytosti“ (Douglas, 1970, s. 9). Etnometodologická výzva totalitním režimům - nevyslovená, implicitní, ale přítomná - poukazovala dále na to, že „absolutistický postoj ke společnosti tvrdí, že lidské činnosti jsou nezávislé na specifických situacích, v nichž probíhají, a to v tom smyslu, že jsou determinovány nějakými faktory vně situace a vně individuálních činností. Absolutistická perspektiva vede ale zpět k idejím vztahu Boha a člověka, jak je nacházíme v tradičním křestanství" (tamtéž) nebo vztahu státu a individua, jak je nacházíme v hobbesovské politologické tradici.

Úkolem sociologie je v tomto pojetí rozpoznat, popsat a analyzovat metody, jichž lidé používají, když svůj sociální svět konstruují jako svưj svět, popsat způsoby, jimiž rozumějí každodennímu životu a jak v něm na základě tohoto porozumění žijí a jednají a jakého jazyka a proč používají. Jazyk je pochopen jako „médium praktické aktivity“ a aktivita jako klíčová sociologická kategorie - aktivita nikoliv v parsonsovském, ale každodenním smyslu, dokonce - „jazyk je způsob dělání věcí (Zimmerman, 1978, s. 10). Na druhé straně tato sociologie ale programově vylučovala všechno, co bylo nad rámec „invariantních elementů sociální interakce“, což srozumitelněji řečeno znamená: „etnometodologie se zabývá těmi strukturami sociální interakce, které jsou invariantní vůči revoluční proměně společenských institucí. Nezabývá se proto přímo takovými otázkami, jako je moc, distribuce zdrojů ve společnosti nebo historickým utvářením institucí (tamtéž, s. 12). Ale i přesto, že konkrétně politický kontext a velké téma moci bylo programově z etnometodologických analýz vyloučeno, zůstala etnometodologie, přesněji snaha zkoumat každodenní život jako fenomén, jako něco, co je hodno vážné pozornosti, razantní výzvou sociologii ve společnostech sovětského typu.

Avšak zatímco v západní sociologii šlo téměř bezvýhradně o dichotomii (sociologie každodennosti) - (scientistický pozitivismus)

nebo $\mathrm{v}$ jiné podobě

(studium běžného vědomí nestandardními prostředky: etnometodologie) - (studium společnosti $z$ „absolutistické perspektivy“: tradiční sociologická teorie plus pozitivistický empirismus),

v zemích s dominujícím oficiálním marxismem šlo o dichotomii zcela jinou, totiž

(studium běžného vědomí) - (oficiální ideologie včetně ideologizované sociologie) nebo $\mathrm{v}$ jiné podobě

(popis reálného životního světa reálných lidí) - (ideologická kamufláž sociální reality). 
$\mathrm{V}$ „západním“ případě šlo o to, že studium běžného vědomí (zdravého rozumu, životního světa, každodennosti) mělo mimo jiné prokázat omezené možnosti tradiční sociologie budované na scientistických principech (věda má přesná pravidla a př̀sný jazyk), v př́ípadě „východním“ mělo studium každodennosti „demaskovat" oficiální ideologii, ukázat, že „reálný socialismus“ ve své „pravé“ realitě je podstatně jiný, než jak jej ukazuje oficiální ideologie ve všech svých podobách.

Zatímco sovětská sociologie běžného vědomí se $\mathrm{v}$ podstatě utopila $\mathrm{v}$ pojmoslovných a definičních debatách, jež tolik milovala, československá sociologie se vzepjala k reálnému činu. Semináře pořádané brněnským sociologem Ivo Možným pod příznačným názvem Socialistický zpưsob života jako sociální realita $(1982,1984,1986,1988)$ byly pokusem o teoretická zamyšlení, ale především o empirické sondy do „reality reálného socialismu“. Hodnota polooficiálních sborníků, do nichž přispěli mj. B. Blažek, J. Kabele, J. Alan, M. Čakrt, J. Musil a další je nesporná, snad již pro šírii tematického záběru: manželství, rodina, urbanizace, stravování, etiketa, domácí práce, „sociologie životních havárií", svátky, časový režim dne atd.

\section{Zdravý rozum jako zbraň proti předsudkům: osvícenství}

Tento exkurs do nedávné minulosti chce ale kromě poukazu na dobové (situační, historické a „indexikálni“ “ $)^{19}$ souvislosti ukázat podstatnější věc, totiž to, že téma „zdravého rozumu“ má většinou nebo dokonce vždycky velmi podobný, analogický kontext - kontext střetu „obyčejného člověka“ (reprezentovaného určitou teorí či ideologií) s mocí (reprezentovanou jinou ideologií). Sám novodobý koncept „zdravého rozumu "se skutečně stává poprvé osovým filozofickým pojmem v podobném kontextu: $\mathrm{v}$ osvícenství totiž plní roli nástroje, který má korigovat především náboženské, ale i jiné předsudky. Klasicky to vyjádřil Holbach: „Aby lidé poznali pravé zásady mravnosti, nepotřebují ani teologii, ani zjevení, ani boha. Potřebují pouze zdravý rozum, potřebují se pouze obrátit do sebe, uvažovat o své přirozenosti, zvážit své skutečné zájmy, přemýšlet o cíli společnosti a všech členů, kteří ji tvoří“ (Holbach, 1959, s. 9, text sám je z roku 1774).

Osvícenská představa, jakkoliv dobově revoluční, převratná, se ukázala nakonec jako omezená a dodnes - jako celé osvícenství - je jablkem sváru.

\section{Scientismus v sociologii 19. století: Marx a Engels}

V době, kdy se sociologie ustavovala jako věda, tedy v době, jíž dominoval (nebo se rozhodně formoval a postupně prosazoval) klasický, tradiční scientismus - přesvědčení, že věda je nejen mocná, ale i přesná, a má-li být vědou v pravém slova smyslu, také vnitřně přesně a pevně (podle jasných metodologických pravidel) zbudovaná byl ale naopak „odpor“ či alespoň nedůvěra ke „zdravému rozumu“ všeobecný. Setkáváme se tak s tradiční „lstí dějin“ či zde dokonce „lstí rozumu“: moderní věda je

19 Indexikalitou se v etnometodologii rozumí podmíněnost interakce a poznání (vědění) komplexem vnějších činitelů, zejména fyzikální a prostorové povahy (kde interakce či poznávací proces probíhá), sociální povahy (s kým se interaguje či od koho se vědění získává) a jazykového rázu (v jakém jazyce v nejširším smyslu probíhá interakce nebo osvojování poznatků a vědění). 
jistě osvícenstvím stimulována a pro některé postmodernisty je dnes model moderní přírodovědy (ne zcela právem) ztotožněn s představou descartovskou (karteziánskou) a osvícenskou (dominantní role Rozumu a vševládné a všezvládající Metody). Věda 19. století, ačkoliv si většinou zachovává svůj antiklerikální etc. ráz, svým radikálním scientismem smete na okraj každého metodologického uvažování byṫ jen zmínku o „zdravém rozumu“.

Proto je ve světové literatuře $\mathrm{k}$ tomuto tématu právem dosti často citována úvaha F. Engelse: „Tento způsob myšlení nám na první pohled připadá velice hodnověrný, protože tak uvažuje takzvaný zdravý rozum. Jenže zdravý rozum je sice v domáckém prostředí úctyhodný chlapík, ale jakmile se pustí do širého světa bádání, zakouší prapodivná dobrodružství...“ (Engels, 1966, s. 47). V Marxově dikci pak: „Nedovedete-li si vysvětlit zisk za tohoto předpokladu, nemůžete jej vysvětlit vůbec. Zdá se to paradoxní a jako by to odporovalo každodennímu pozorování. Ale právě tak paradoxní je to, že se země točí kolem slunce a že se voda skládá ze dvou vysoce zápalných plynů. Vědecká pravda je vždycky paradoxní z hlediska každodenní zkušenosti, která poskytuje jen klamné zdání věcí (Marx, 1977, s. 552).

Celá marxovsko-engelsovská polemika se zdravým rozumem, která zdaleka není ve své době osamocena, je ovšem založena na ontologickém rozlišení zásadního významu, totiž rozlišení podstaty, $\mathrm{k}$ níž se můžeme dobrat jen vědeckým poznáním (jaký smysl by měla věda, kdyby podstaty byly okamžitě viditelné, ptá se kdesi Marx), ${ }^{20}$ a jevu, který je dostupný každodennímu poznání a pozorování. Tuto dichotomii - dichotomii podstaty a jevu (přes Leninovo dialektické upozornění, že „podstata se jeví a jev je podstatný“')21 napadá pozdně moderní a postmoderní sociologie. Víceméně právem. V dikci Václava Bělohradského jde o nezbytnost věnovat pozornost povrchu, který vypovídá o věcech a procesech více než metafyzické podstaty tradiční filozofie.

\section{Pozitivistický scientismus: Durkheim}

Podobně jako Marx s Engelsem uvažuje o několik málo let později Durkheim, který tvrdí, že sociologie mohla vzniknout pouze za dvou předpokladů, totiž:

že si vědci uvědomili, že stejně jako platí zákonitosti (zejména zákon přičinné souslednosti, kauzálního nexu) pro oblast živé a neživé přírody, platí se stejnou závazností podobné zákonitosti i pro oblast sociálního života a

že se sociální věda, chce-li opravdu být vědou, radikálně oprostí od představ „běžné zkušenosti“: ty totiž mají jedinou funkci, totiž uvést naše činy do souladu se světem každodennosti (termín není Durkheimův), mají tedy funkci povýtce pragmatickou, utilitární a žádnou jinou, rozhodně ne kognitivní, poznávací.

Durkheim radikálně a razantně rozlišuje individuální rozum, jehož poznávací hodnota je omezená a z hlediska vědeckého poznání žádná, a kolektivní rozum, který je rezervoárem nejen sociální zkušenosti jednotlivých individuí, ale společnosti celé -

20 Poznámka editorů: Tutéž myšlenku reprodukuje Kosík: „Kdyby se jevová forma a podstata věcí př́mo kryly, byla by věda a filosofie zbytečná" (1963, s. 12-13). Odkazuje přitom hned na tři různá místa v Marxově díle.

21 Poznámka editorů: Tato teze bývá připisována Hegelovi; sám Lenin ji patrně diskutuje právě v přímé souvislosti s Hegelem. 
jeho kognitivní hodnota je proto enormně vyšší. Nad tím vším ale stojí rozum vědy „rozum, jehož se dovolávám, je rozum metodicky zkoumající danou látku..., aby zjistil, co to je a $\mathrm{z}$ toho vyvodil praktické závěry. Takto pojímaný rozum je prostě věda" (Durkheim, 1998, s. 82). Podle Durkheima je kognitivní hodnota poznatků každodenní zkušenosti nepatrná, a proto ani nemá smysl je podrobovat analýze - „tím, že je zpracováváme, neodhalíme nikdy zákony skutečnosti, at děláme cokoliv“ (Durkheim, 1926, s. 58).

A toto je nejen nejradikálnější vyjádření opozice, ba odporu ke zdravému rozumu v dějinách sociologie, ale taky vlastně anticipativní polemika s etnometodologií, která právě ono Durkheimem odmítané běžné vědomí činí předmětem svého dominantního zájmu (aby to však mohla učinit, musí odmítnout Durkheimovu premisu, že totiž „pod povrchem“ každodenní zkušenosti leží „zákony skutečnosti“, jež odhalovat je povolána sociologie - což také kategoricky činí) a Durkheima předmětem své zlobné i věcné kritiky. Velmi věcně ukazuje na jistou vnitřní rozpornost Durkheimova sociologismu a radikálního odmítnutí „subjektivních elementư “ Paul Filmer:

1. Durkheim sdílí primitivní pozitivistickou premisu, která ovšem vychází ze zdravého rozumu, že „, základech všeho poznání nutně spočívá víra v existenci objektivního světa" (Filmer et al., 1972, s. 67). Podle Durkheima tedy způsob konstrukce tohoto světa prostřednictvím každodenních interpretačních procedur, jež jsou vlastní individuím a to, jak se takto konstruovaný svět stává předmět výzkumu, nelze a není nutno problematizovat. To ale znamená, že předmětem studia se de facto stává onen svět, který měl být „,ědecky“ eliminován.

2. Durkheim podléhá iluzi, že zkoumá „sociální fakta“ - tato iluze roste př́mo úměrně tomu, jak přenáší svou pozornost na studium společenského, kolektivního vědomí. Ačkoliv se ve spisu o sebevraždě snaží prokázat, že statisticky doložené souvislosti mezi činiteli, jež ovlivňují sebevražednost, nelze vysvětlit z významů, které takové souvislosti přikládají aktéŕi, ve skutečnosti se nakonec roli přikládaných významů vyhnout nemůže (tamtéž, s. 92).

Sociologie konce 20. století: obrat ke každodennosti a návrat ke zdravému rozumu

Nebudeme vyprávět celý „př́iběh zdravého rozumu“ v běhu dějin moderní sociologie (samozřejmě, že neopozitivistická sociologie zdravý rozum zpochybnila v duchu svého scientistického paradigmatu - viz výše uvedené pŕíklady typu výzkum versus zdravý rozum). Snad postačí, když připomeneme, že ke zpochybnění scientistického předpokladu, že mezi vědeckým poznáním společnosti a pohledem zdravého rozumu na ni je podstatný rozdíl, došlo poprvé až v 60 . letech našeho století v souvislosti s nástupem fenomenologické či interpretativní sociologie a zejména etnometodologie, a to v podobě více než razantní. Tento obrat ke každodennosti a zdravému rozumu otřásl celou pozdně moderní sociologií a úzce souvisí s tím, co bychom označili jako „postmodernizaci“ sociologie - je totiž jejím předchůdcem i součástí.

Etnometodologie svým akcentem na každodennost a zdravý rozum sleduje tř̀ propojené cíle: 
1. povýšit každodenní aktivity (každodennost) na centrální sociologické téma a vyloučit existenci jiných, „hlubších“ nebo „vyšších“ strukturálních úrovní reality (jako jsou sociální struktury, tř́idy, instituce atd., které existují jen jako naše konstrukce a ještě lépe jako více méně užitečné konstrukce sociologů),

2. prokázat, že zdravý rozum, běžné vědění je základem i předpokladem smysluplného jednání v sociálním světě - jiné a „lepšíi vědění nemáme a mít nemưžeme a je proto dostatečně relevantním předmětem sociologického studia a

3. každá sociologie $z$ vědění zdravého rozumu nutně vychází, sociologické koncepce se od sebe liší jenom mírou, v níž to připouštějí (nebo popírají).

V pěkné formulaci Davida Walshe: „Sociologické porozumění sociálnímu světu, jež by překonalo úzké hranice zdravého rozumu, si musí stavět a řešit problémy jiného řádu než ty, které si klade běžné, každodenní vědění, zdravý rozum sám. Takového porozumění lze dosáhnout jen studiem procesů interpretace, $v$ jejímž průběhu a jejímž prostřednictvím členové společnosti (včetně sociologů) konstruují (utvářejí) a poznávají sociální svět. A k tomu je nutná analýza metod praktikovaných v každodenním životě k racionálnímu objasnění sociálního světa“ (Filmer et al., 1972, s. 68). Tak je i vymezen predmět etnometodologie, jímž je každodennost jako „ontologické“ podloží a předmět racionalizačních praktik (etnometod), tedy postupů, jimiž rozumíme světu, činíme jej srozumitelný a společně sdělný s ostatními.

Jack Douglas tvrdí, že „všechny fundamentální ideje sociologie každodennosti“ (Douglas, 1980, s. X) jsou obsaženy v symbolickém interakcionimsu, v „enigmatické sociologii“ Ervinga Goffmana, etiketizační teorii a teorii každodenní deviace, fenomenologické sociologii a etnometodologii a v existencialistické sociologii, tedy v těch směrech, jež položily základ pestrobarevnému, ale jednotnému „hnutí postmoderní sociologie. Sociologie každodennosti je „sociologická orientace, která se zabývá zkušeností, pozorováním porozuměním, popisem a analýzou komunikace lidí interagujících v konkrétních situacích“ (tamtéž). Podstatný pak je pojem situace, která - aby byla smysluplným předmětem sociologické analýzy - musí být

- prirozená, tj. musí to být situace, do níž neintervenuje věda a vědecké poznávání, musí být „nezávislá na vědecké manipulaci“ (zkoumání interakce v přirozených, „naturálních“ podmínkách se v tomto typu sociologie běžně rríká „naturalistický přístup“, což je ovšem v rozporu s ustálenou tradicí z dějin sociologie), ${ }^{22}$

- konkrétní, tj. taková, že se v ní jedinec opravdu konkrétně, reálně atd. angažuje,

- významová, tj. je založena na významech, jež sdílejí členové skupiny (účastníci interakce), sociolog proto na ni při výzkumu nesmí klást významy jiné než má ona sama ve vědomí a hlediscích aktérů.

Mnozí analytici ale ukazují, že takový pohled je poněkud umělý v tom smyslu, že čistého „zdravého rozumu“ a čistých „přirozených situací" v moderní společnosti není. Thomas Luckmann, který jako spolutvůrce (s Peterem Bergerem) sociálního konstruktivismu má k věci jistě co říci, píše: „Růst specializovaného vědění způsobuje pokles podílu zdravého rozumu mezi členy moderní společnosti. Je to právě absence zdravého

22 Naturalismus či naturalistický př́stup v postmoderní sociologii znamená „zkoumání v přirozených podmínkách“ - tak existuje např́klad „naturalistická mikrosociologie“, která zkoumá individua v přirozených (nikoliv experimentálně utvořených) malých skupinách, zatímco v tradiční sociologii je „naturalismus" způsob konstrukce sociologie podle pravidel prírodních věd (natura - príroda). 
rozumu, která vede jak k nerealistickým aspiracím připisovaným vzdělání, tak ke konfliktům mezi sociálními skupinami“ (Luckmann, 1987, s. 9). Luckmann také realističtěji charakterizuje zdravý rozum, když konstatuje, že zdravý rozum neboli subjektivní vědění má tyto znaky:

- je založeno na osobní a jen osobní zkušenosti a tvoří „subjektivní balík věděni'"23;

- není založeno na logické systemizaci, ačkoliv tvoří souhrn logicky uspořádaných prvků;

- reflektuje zkušenost z partikulárních situací a „sedimentuje“ ji;

- obsahuje stabilizované modely řešení (standardních) problémů;

- je transmitováno (přenášeno) speciálními institucemi (v preliterární společnosti rodinou, ústní, orální poezií, náboženskými rituály, dnes školou, výukou, knihovnami a muzei, dodejme - masovými médii);

- je nerovnoměrně distribuováno, distribuce tohoto vědění je různá a

- „zdravý rozum“, tedy subjektivní vědění, je silně stratifikován.

Luckmann upozorňuje na podstatný fenomén nejen stratifikace zdravého rozumu (neexistuje jeden společný zdravý rozum, ale odlišné objemy a obsahy subjektivního vědění závislé na sociální pozici, jinak - existují subjektivní vědění typicky příslušná odlišným sociálním pozicím). ${ }^{24}$ Luckmann shrnuje:

„Zdravý rozum, protože je obecným věděním, jež přísluší ke každodenním reáliím a je tedy ústřední součástí sociálního balíku vědění, slouží k poskytování celkové orientace pro individuum, a proto musí odpovídat na výzvu všech druhů normálních situací v životě. Taková orientace je existenciální a musí být proto partikularizována, musí být konkrétní... Struktura tohoto vědění je sice fenomenologicky analyzovatelná, ale běžné individuum si ji neuvědomuje. Není mu dostupná dotud, dokud neopustí husserlovský přirozený postoj, postoj zdravého rozumu... Věda budovaná na empirických principech verifikace nebo koroborace ${ }^{25}$ je vědění, které odpovídá výlučně té realitě, jejíž projevy jsou přístupné každému v každodenním životě, a to bez ohledu na to, jak jsou vzdáleny její pojmy od úrovně každodenní zkušenosti a jak nesrozumitelné jsou její formule zdravému rozumu. Domácí základ (home base) moderní vědy je také domácím základem zdravého rozumu. Věda stejně jako zdravý rozum spočívají na nějaké formě realismu, který je filozoficky naivní. Filozoficky naivní realismus může být při konečné, definitivní analýze shledán neadekvátním, ale v ohlupování lidí je úspěšný - ve vědě po dlouhou dobu, ve zdravém rozumu vždycky a stále“ (Luckmann, 1987, s. 194).

Luckmannova otázka proto zní - je možné, nutné a žádoucí racionalizovat zdravý rozum, který stojí na naivní realistické premise o „objektivní existenci světa“? Luckmann

${ }^{23}$ Pojem je parafrází na Schützův termín „balík př́ručního věděni“, jímž se rozumí disponibilní vědění, jež individuum používá zejména k rozpoznávání a „typifikaci“ sociálních situací a jež obsahuje předchozí zkušenost př́mou i zprostředkovanou. Schütz se tématem „zdravého rozumu“ zabýval jako tématem sociologicky prvořadým vůbec poprvé.

24 Tento motiv se v podstatně pozměněné podobě objeví u Pierra Bourdieua, který ukáže nerovnoměrné rozdělení kulturního kapitálu, jenž je v jistém smyslu také „sociálním subjektivním věděním“.

25 Pojem koroborace je poněkud komplikovaný termín specifický pro epistemologii Karla Poppera. Popper koroborací rozumí „informaci, která hodnotí fungování teorie“ a která umožňuje rozlišit, která teorie je lepš́: jestliže teorie projde úspěšně všemi testy, máme dostatečný důvod se domnívat, že tato teorie má vyšší hodnotu než jiná teorie, která ji předcházela. U Poppera jde o subtilní problém vztahu „koroborovatelnosti, testovatelnosti a logické pravděpodobnosti“ (srv. Popper, 1997, kap. X), Popper se s odkazem na Alfreda Tarského snaží také rehabilitovat moderní pojetí pravdy. 
neví. Zdá se, že odpověd je ale přítomna v procesech, jichž jsme svědky v současném světě - v globalizaci, medializaci, informatizaci a zejména v proměně tradiční moderní společnosti v „network society“: zdravý rozum je prosycen „vědeckým pohledem“ na svět, přestává být zdravým rozumem v tradičním, klasickém smyslu a stává se směsicí přirozeného postoje, sedimentovaného vědění (vlastní a cizí životní zkušenosti) a většinou „pokleslé“, popularizované a vulgarizované vědy. V pozdně moderní společnosti padla nejen představa nositele „selského(!) zdravého rozumu“, ale zmizel tento nositel sám. Nikoliv náhodou se mluví o „selském rozumu“, protože v této metafoře je fixován fakt, že jeho nositel patří do tradiční společnosti. Literárním prototypem jsou samozřejmě všechny románové postavy Holečkovy (Naši ) nebo Mrštíků (Rok na vsi), především ovšem Němcové babička Novotná, toto světlé ztělesnění „lidové moudrosti“. Není však více tradiční lidové moudrosti, která věděla všechno možné o počasí, pěstování včel, domácích pracích a životě zvířat i lidí, protože přirozený svět současného člověka se radikálně proměnil. Jeho symbolem je fialová kráva Milka a roztomile přihlouplé hlasatelky zpráv o počasí snad na všech televizních kanálech světa. Lindenberg (volně dle 1987, s. 199) shrnul redukované funkce zdravého rozumu v naší době takto (komentáře doplněny):

1. Funkce sjednocující (základová, bazální): předpokládáme, že existuje společný svět, který je základem společné interakce a zdravý rozum nám poskytuje základní prostředky, jak se v interakčních situacích orientovat a chovat;

2. Funkce referenční: máme zhruba stejné představy o tom, co je možné a co nikoliv, takže dokážeme odlišit realitu (možnou a skutečnou, aktuální a budoucí) od pohádky, mýtu, vyprávění, sci-fi atd. - připouštíme, že věci, lidé a vztahy mohou být velmi odlišné $\mathrm{v}$ různých částech světa, $\mathrm{v}$ různých dobách a v různých situacích, ale známe mez odlišnosti, za níž začíná „fantazie“, jíž nic neodpovídá (v klasické terminologii - „nemá referenta" či referenci),

3. Funkce apelační: protože sdílíme základní výchozí představy o světě a základní pravidla interakčního a komunikačního styku, není nutné v každé situaci argumentovat, dokazovat a přesvědčovat, stačí „apelovat“ odkazem na určitou normu, pravidlo či zvyklost a tím „donutit“ druhého k tomu, aby pravidlo či normu respektoval.

Shrňme tedy. Teoretická sociologie 20. století (samozřejmě s výjimkou fenomenologické sociologie) téma zdravého rozumu, každodennosti a běžných životních aktivit v podstatě ignorovala a pokoušela se zbudovat svůj obraz společnosti podle osvědčených scientistických receptů, zejména na premise zmíněného "absolutistického postoje ke světu“, který rozlišuje „vyšší“ a „nižší “ řád společenské skutečnosti. Empirická sociologie pak plně přijala předpoklad, že opravdové vědění o společnosti se zakládá na schématu „hypoté$z a$ - operacionalizace - verifikace - kvantifikace - deskripce - interpretace (explanace)“, a co nad to jest, od zlého jest. Jack Douglas (a mnozí jiní po něm) ale ukazuje, že ani sociologická teorie tradičního střihu, ani empirický výzkum nemohou ignorovat poznatky zdravého rozumu, které do sociologie prostě vstupují „zadními vrátky“: je to tím horší, že jsou nereflektovány, neuvědomovány a neanalyzovány.

Sociologie tedy vykonala svou tradiční pout „tam a zase zpátky“, tentokráte takto: od odmítnutí zdravého rozumu jako „znečištující příměsi“ v tradičně scientistickém (zejména pozitivistickém) modelu vědy přes adoraci zdravého rozumu jako „jediného pravého tématu“, bez něhož se žádná skutečná sociologie neobejde, k relativizaci zdravého rozu- 
$m u$, který se do té míry proměnil, že stojí za zkoumání především jako dynamicky se měnící objekt - sám o sobě však žádnou vědu zakládat nemůže. ${ }^{26}$

\section{LITERATURA}

Bauman, Z. (1962). George Lundberg, czyli dehumanizacja humanistyki. Studia filozoficzne, (4), 3-38. Bauman, Z. (1987). Legislators and Interpreters: On Modernity, Post-modernity and Intellectuals. Cambridge: Polity Press.

Bauman, Z. (2002). Tekutá modernita. Praha: Mladá fronta.

Bauman, Z. (2006). Úvahy o postmoderní době. Praha: Sociologické nakladatelství (SLON).

Bělohradský, V. (1997). Mezi světy a mezisvěty. Praha: Votobia.

Benda, J. (1929). Zrada vzdělanců. Praha: Spolek výtvarných umělců Mánes.

Douglas, J. D. (1970). Understanding Everyday Life. In J. D. Douglas (ed.), Understanding Everyday Life: Toward the Reconstruction of Sociological Knowledge (s. 3-44). Chicago: Aldine.

Douglas, J. D. (ed.) (1980). Introduction to the Sociologies of Everyday Life. Boston: Allyn \& Bacon.

Durkheim, E. (1926). Pravidla sociologické metody. Praha: Orbis.

Durkheim, E. (1998). Sociologie a filosofie. Praha: Sociologické nakladatelství (SLON).

Engels, B. (1966). Dialektika př́rody. In K. Marx, B. Engels, Spisy, sv. 20. Praha: Svoboda.

Engels, B. (1978). Dopis W. Borginsovi. In K. Marx, B. Engels, B., Vybrané spisy, sv. 5. Praha: Svoboda. Feyerabend, P. K. (2001). Rozprava proti metodě. Praha: Aurora.

Filmer, P., Phillipson, M., Silverman, D., \& Walsh, D. (1972). New Directions in Sociological Theory. London: Collier-Macmillan.

Gleick, J. (1996). Chaos: Vznik nové vědy. Brno: Ando Publishing.

Holbach, P. H. D. von. (1959). Zdravý rozum neboli Přirozené představy v protikladu k představám nadpřirozeným. Praha: SNPL.

Hymes, D. H. (1979). Comments on Michael A. Overington. The American Sociologist, 14 (1), 24-26.

Johnson, P. (1996). Intelektuálové. Praha: Návrat domů.

Joseph, M. (1986). Sociology for Everyone. Cambridge: Polity Press.

Kapr, R., \& Šafár, Z. (1969). Sociologie nebo zdravý rozum? Praha: Mladá fronta.

Keller, J. (1995). Dvanáct omylů sociologie. Praha: Sociologické nakladatelství (SLON).

Kosík, K. (1963). Dialektika konkrétního: Studie o problematice člověka a světa. Praha: Nakladatelství ČSAV.

Lindenberg, S. (1987). Common Sense and Social Structure: A Sociological View. In F. L. van Holthoon \& D. R. Olson (eds.), Common Sense: The Foundations for Social Science (s. 199-216). Lanham: University Press of America.

Luckmann, T. (1987). Some Thoughts on Common Sense and Science. In F. L. van Holthoon \& D. R. Olson (eds.), Common Sense: The Foundations for Social Science (s. 162-190). Lanham: University Press of America.

Madge, J. (1963). The Origins of Scientific Sociology. London: Tavistock.

Machotka, O. (1949). Is Sociology a Natural Science? American Journal of Sociology, 55 (1), 10-17.

Marcuse, H. (1965). Repressive Tolerance. In R. P. Wolff, B. Moore Jr. \& H. Marcuse, A Critique of Pure Tolerance (s. 81-117). Boston: Beacon Press.

Marx, K. (1977). Mzda, cena a zisk. In K. Marx, B. Engels, Vybrané spisy, sv. 2. Praha: Svoboda.

${ }^{26}$ Poznámka editorů: V rukopisu dále následuje poznámka „Schéma: Zdroje a efekty zdravého rozumu“, není však bohužel známo, jak konkrétně mělo schéma vypadat. Dokument pokračuje zhruba deseti rukopisnými stranami nadepsanými titulkem „Sociologie a literatura: věda a a,vyprávění jako základní paradigmatický rozštěp pozdně moderní sociologie“. Téma zdravého rozumu a každodennosti zde Petrusek zasazuje do kontextu „rozštěpu mezi scientistickou a narativistickou větví a následně formuluje deset „výchozích tezí „o sociologii, vědě a zdravém rozumu“. Z prostorových důvodů jsme se ovšem rozhodli text na tomto místě ukončit s tím, že závěrečná pasáž snad bude v budoucnu publikována na jiném místě. 
O'Neill, J. (1972). Sociology as a Skin Trade: Essays towards a Reflexive Sociology. New York: Harper \& Row.

O'Neill, J. (1975). Making Sense Together: An Introduction to Wild Sociology. London: Heineman.

Overington, M. A. (1979). Doing the What Comes Rationally: Some Developments in Metatheory. The American Sociologist, 14(1), 2-12.

Patočka, J. (1990). Kacírské eseje o filosofii dějin. Praha: Academia.

Petrusek, M., \& Reifová, I. (1997). Deset otázek profesoru Zygmuntu Baumanovi. Sociologický časopis, 33 (2), 203-216.

Popper, K. R. (1997). Logika vědeckého zkoumání. Praha: OIKOYMENH.

Soboul, A. (1954). Encyklopedie aneb Racionální slovník věd, umění a řemesel. Praha: SNPL.

Spinoza, B. de. (1986). Etika. Bratislava: Pravda.

Stouffer, S. A., Suchman, E. A., Devinney, L. C., Star, S. A., \& Williams, R. M., Jr. (1949). The American Soldier: Adjustment during Army Life. Princeton University Press.

Střítecký, J. 1994. Mohl se TGM stát rakouským Durkheimem? In I. Chovančíková (ed.), Tomáš Garrigue Masaryk a sociologie: Sborník př́spěvků z II. ročníku semináře Masarykova muzea v Hodoníně 18. listopadu 1993 (s. 19-25). Hodonín: Masarykovo muzeum v Hodoníně.

Toffler, A. (1985). Trzecia fala. Warszawa: PIW.

Toffler, A. (1991). Powershift: Knowledge, Wealth, and Violence at the Edge of the 21st Century. New York: Bantam Books.

Toffler, A. (1992). Šok z budoucnosti. Praha: Práce.

Toffler, A. (1994). Previews and Premises. London: Pan Books. 